\title{
Upaya Meningkatkan Motivasi Dan Prestasi Belajar Pada Pembelajaran Matematika Melalui Model Pembelajaran Teams Games Tournament (TGT) Pada Siswa SMA Negeri 2 Gorontalo
}

\author{
Yolan K. Hamzah \\ Guru SMA Negeri 2 Gorontalo \\ yolanhamzah@gmail.com
}

Received: 04 March 2021; Revised: 26 April 2021; Accepted: 28 August 2021

DOI: http://dx.doi.org/10.37905/aksara.7.3.1171-1178.2021

\begin{abstract}
ABSTRAK:
Penelitian ini dilaksanakan melalui tiga siklus. Untuk melihat motivasi belajar matematika siswa kelas X pada SMA Negeri 2 Gorontalo maka dilakukan observasi kegiatan pembelajaran yang dilakukan oleh peneliti sendiri dan guru lain yang setiap hari menjadi team teaching di kelas tersebut.

Dari hasil uji coba diperoleh Motivasi belajar matematika siswa secara umum mengalami kenaikan rata-rata motivasi minimal cukup baik yang awalnya sebesar $75 \%$ siswa menjadi sebesar $90 \%$ siswa di kelas X. Hal ini menurut analisis peneliti dikarenakan sebagai berikut: (1) Siswa senang dengan variasi model pembelajaran yang menurut mereka baru dan belum pernah mereka dapat sebelumnya (2) Materi pembelajaran yang dibahas relatif dapat dipahami oleh siswa karena di jenjang sekolah sebelumnya pernah diajarkan. Hasil tes yang dilaksanakan pada setiap siklus mengalami kenaikan, kecuali pada siklus III. Pada siklus I nilai rata-rata sebesar 65,40, pada siklus II nilai rata-rata sebesar 69,00 dan pada siklus III nilai rata-rata sebesar 68,00. Hal ini menurut pengamatan dan pengalaman peneliti dikarenakan bagi siswa materi pada siklus III mengenai jajargenjang relatif lebih sulit dari materi pada siklus I dan II.
\end{abstract}

\section{Kata Kunci : model pembelajaran, motivasi dan prestasi belajar, matematika}

\section{PENDAHULUAN}

Matematika bagi sebagian besar siswa adalah mata pelajaran yang tidak disukai bahkan dibenci. Hasil survei sederhana yang dilakukan peneliti setiap awal tahun, jika ada pertanyaan mata pelajaran apa yang disukai siswa, maka jawabannya hampir $90 \%$ siswa menjawab selain mata pelajaran matematika. Sebaliknya jika ditanya mata pelajaran apa yang tidak disukai, maka hampir $75 \%$ menjawab matematika.

Celakanya fakta ini berlanjut sampai ditingkat pendidikan dan proses kegiatan belajar mengajar. Hal ini ditunjukkan oleh sikap siswa yang sebagian besar kurang antusias ketika pelajaran akan berlangsung, rendahnya respon umpan balik dari siswa terhadap pertanyaan dan penjelasan guru serta pemusatan perhatian terhadap pelajaran yang kurang, sebagian besar siswa pasif, mereka tidak berani berbicara tentang apa yang sudah dan belum diketahui, konsep-konsep mereka benar atau salah sulit diketahui guru, meskipun guru telah berusaha menjelaskan materi dengan semaksimal mungkin. 
Berbagai macam cara digunakan baik oleh sekolah maupun guru-guru dengan harapan dapat meningkatkan prestasi belajar matematika. Usaha-usaha tersebut antara lain dengan jam tambahan kelas X dan bahkan guru-guru mengadakan kegiatan kelompok mengajar atau sering disebut dengan "team teaching". Pada kegiatan tersebut satu kelas diajar oleh dua orang guru dimana satu guru menjadi guru model (mengajar di depan kelas) dan satu orang guru menjadi observer (mengamati jalannya pelajaran di belakang siswa).

Untuk mengatasi kurangnya motivasi siswa dalam pelajaran matematika maka perlu usaha peningkatan motivasi dengan memberi variasi model pembelajaran yang bersifat Cooperative Learning yang menarik atau menyenangkan, yang melibatkan siswa, yang dapat meningkatkan aktivitas dan tanggung jawab siswa.

Banyak model pembelajaran yang dapat diterapkan dalam proses belajar mengajar. Salah satunya adalah model pembelajaran dengan tipe "Teams Games Tournament" atau biasa disingkat TGT. Dalam TGT siswa melakukan permainanpermainan dengan anggota-anggota tim lain untuk memperoleh skor bagi tim mereka masing-masing. Dengan suasana permainan dalam pembelajaran maka diharapkan akan menarik dan menimbulkan efek rekreaktif dalam belajar siswa. Aktivitas belajar dengan permainan yang dirancang dalam model pembelajaran Cooperative Learning dengan tipe TGT memungkinkan siswa dapat belajar lebih rileks disamping menumbuhkan tanggung jawab, kerjasama, persaingan sehat dan keterlibatan belajar.

\section{METODE PENELITIAN}

Untuk melihat motivasi belajar matematika siswa kelas X pada SMA Negeri 2 Gorontalo maka dilakukan observasi kegiatan pembelajaran yang dilakukan oleh peneliti sendiri dan guru lain yang setiap hari menjadi team teaching di kelas tersebut. Setelah dilakukan pengkajian reflektif dan diskusi, maka ditetapkan tindakan untuk meningkatkan motivasi siswa dalam belajar matematika dengan model pembelajaran kooperatif dengan tipe Teams Games Tournament (TGT).

Penelitian tindakan kelas ini direncanakan dalam 3 siklus, yang tiap-tiap siklusnya mencakup tahapan berikut.

1. Perencanaan (Planning)

Perencanaan tindakan meliputi penyusunan rencana pembelajaran, membuat skenario pembelajaran dengan teknik Teams Games Tournament (TGT), membuat media permainan sesuai dengan tema dalam rencana pembelajaran dengan Teams Games Tournament (TGT) yang dilengkapi dengan petunjuk kegiatan dan aturan permainan, serta penyusunan alat-alat evaluasi tindakan.

2. Tindakan (Acting)

Implementasi tindakan atau pelaksanaan tindakan meliputi :

a. Pembuatan kelompok-kelompok belajar yang terdiri dari empat orang siswa dengan kemampuan heterogen.

b. Membagi petunjuk kegiatan atau aturan permainan pada tiap kelompok

c. Siswa melaksanakan permainan sesuai dengan petunjuk kegiatan.

d. Masing-masing anggota berkompetensi untuk mendapatkan nilai.

3. Pengamatan/Observasi (Observing)

Observasi pelaksanaan pembelajaran dilakukan secara kolaboratif dengan menggunakan instrument monitoring yang telah direncanakan. Data tentang 
kondisi pembelajaran matematika diperoleh dari lembar observasi yang diisi observer. Data tentang tingkat kemajuan motivasi belajar matematika pada siswa diperoleh dari lembar angket yang diedarkan setelah kegiatan pembelajaran pada setiap siklus berakhir. Dan data tentang hasil belajar siswa diperoleh dari hasil evaluasi yang berupa tugas dan ulangan harian.

4. Refleksi (Reflecting)

Refleksi dilakukan berdasarkan hasil wawancara dengan siswa, hasil lembar pengamatan dan hasil diskusi dengan guru . Hasil refleksi digunakan untuk menentukan langkah-langkah tindakan berikutnya.

Teknik pengumpulan data dalam penelitian ini adalah:

1. Observasi (pengamatan) yaitu untuk mengetahui situasi dan proses pelaksanaan kegiatan belajar mengajar yang berlangsung di kelas.

2. Angket (kueisoner) untuk memperoleh data motivasi belajar matematika siswa melalui model pembelajaran kooperatif tipe TGT. Tes yaitu untuk memperoleh data hasil belajar siswa

Penelitian ini berhasil apabila motivasi belajar matematika siswa mengalami peningkatan rata-rata motivasi dengan kategori minimal cukup baik dan juga prestasi belajar mengalami peningkatan dari siklus satu ke siklus selanjutnya

\section{HASIL DAN PEMBAHASAN \\ Hasil Penelitian \\ Siklus 1}

Kegiatan pembelajaran pada siklus I dilaksanakan sebanyak 1 kali pertemuan dan setiap pertemuan berlangsung selama 2 jam pelajaran ( 2 x 45 menit).

a. Perencanaan dan Persiapan Tindakan

Perencanaan dan persiapan tindakan yang dilakukan peneliti meliputi:

1). Menyusun Rencana Pelaksanaan Pembelajaran (RPP) materi persegi panjang.

2). Menyiapkan langkah-langkah pada model pembelajaran TGT

3). Menyiapkan lembar observasi pembelajaran

4) Menyiapkan LKS

5). Menyiapkan kartu soal untuk tournamen

6). Menyiapkan blangko nilai pada setiap meja kelompok dan blangko nilai kelompok.

b. Pelaksanaan Tindakan

Kegiatan pelaksanaan pembelajaran pada siklus 1 ini dilaksanakan satu kali pertemuan dengan langkah-langkah yaitu:

1) Guru menjelaskan materi tentang persegi panjang.

2) Siswa membentuk kelompok belajar dan berdiskusi

3) Permainan (game tournament)

4) Penghargaan kepada kelompok.

Pada tahap ini, kegiatan pembelajaran dimulai dengan menjelaskan materi mengenai persegi panjang dengan metode demonstrasi dan tanya jawab. Pada akhir penjelasan guru memberikan kesempatan kepada siswa untuk menanyakan kembali materi yang kurang dimengerti sebelum kegiatan diskusi kelompok dilaksanakan. 
Setelah pemberian materi selesai dilaksanakan siswa dikelompokan menjadi 10 (sepuluh) kelompok dengan masing-masing beranggotakan 4 (orang) orang siswa sesuai dengan format pembentukan kelompok belajar siswa yang telah ditentukan pada Pra Kegiatan. Kemudian guru membagikan LKS materi persegi panjang untuk didiskusikan setiap kelompok.

c. Pengamatan

Pelaksanaan pengamatan proses pembelajaran pada siklus ini, siswa sebagian besar antusias mengikuti pembelajaran, hal ini terlihat dari banyaknya siswa yang menanggapi setiap pertanyaan yang diajukan oleh guru mengenai materi yang diajarkan yaitu materi persegi panjang. Hal lain yang membuat siswa antusias, dari pemberitahuan sebelumnya bahwa nanti dalam pembelajaran ini ada kegiatan permainan. Bahkan sebagian siswa bertanya kepada peneliti permainan yang bagaimana yang membuatnya mereka penasaran.

Hasil evaluasi yang diperoleh oleh siswa setelah pelaksanan model pembelajaran TGT ini menunjukkan hasil rata-rata kelas 65,40, hal ini bisa terlihat dari lampiran.

d. Refleksi

Dari hasil pengamatan mengenai diskusi kelompok terlihat kurangnya kerja sama dari setiap anggota kelompok, peneliti dan guru observer menyimpulkan bahwa hal ini dikarenakan ada beberapa anggota yang kurang bersemangat dalam belajar, hal ini ditunjukkan dengan hasil angket motivasi belajar sebagai berikut.

Hasil angket motivasi belajar siswa pada siklus I menunjukkan adanya motivasi siswa dengan kriteria sangat baik sebesar 9,20\%, kriteria baik sebesar $30,30 \%$, kriteria cukup baik sebesar 35,50 \% dan kriteria kurang baik $25 \%$. Hal ini menunjukkan sebanyak $75 \%$ siswa di kelas X mempunyai motivasi meskipun motivasi yang paling rendah hanya cukup baik.

Dari hasil pengamatan mengenai kegiatan permainan, terlihat beberapa siswa masih belum paham peraturan-peraturan (langkah-langkah) permainan, oleh sebab itulah pada siklus II guru memberi penjelasan secara terinci mengenai langkah-langkah permainannya, dan guru lebih berperan sebagai motivator baik dalam diskusi kelompok maupun dalam kegiatan permainan.

Dari hasil evaluasi yang menunjukkan hasil rata-rata kelas 65,40 , ini berarti sudah memenuhi kriteria ketuntasan belajar yang ditetapkan oleh guru mata pelajaran sebesar 63,00.

\section{Siklus II}

Kegiatan pembelajaran pada siklus II dilaksanakan sebanyak 1 kali pertemuan dan setiap pertemuan belangsung selama 2 jam pelajaran ( 2 x 45 menit).

a. Perencanaan dan Persiapan Tindakan

Perencanaan dan persiapan tindakan yang dilakukan peneliti meliputi:

1). Menyusun Rencana Pelaksanaan Pembelajaran (RPP) dengan revisi sesuai refleksi siklus I pada materi persegi.

2). Menyiapkan langkah-langkah pada model pembelajaran TGT

3). Menyiapkan lembar observasi pembelajaran

4) Menyiapkan LKS

5). Menyiapkan kartu soal untuk tournamen 
6). Menyiapkan blangko nilai pada setiap meja kelompok dan blangko nilai kelompok.

b. Pelaksanaan Tindakan

Kegiatan pelaksanaan pembelajaran pada siklus 1 ini dilaksanakan satu kali pertemuan dengan langkah-langkah yaitu:

1) Guru menjelaskan materi tentang persegi.

2) Siswa membentuk kelompok belajar dan berdiskusi

3) Permainan (game tournament)

4) Penghargaan kepada kelompok.

Pada tahap ini, kegiatan pembelajaran dimulai dengan menjelaskan materi mengenai persegi dengan demonstrasi dan metode tanya jawab. Pada akhir penjelasan guru memberikan kesempatan kepada siswa untuk menanyakan kembali materi yang kurang dimengerti sebelum kegiatan diskusi kelompok dilaksanakan.

Setelah pemberian materi selesai dilaksanakan siswa dikelompokan menjadi 10 (sepuluh) kelompok baru yang dibentuk berdasarkan tes formatif setelah siklus I dengan masing-masing beranggotakan 4 (empat) orang. Kemudian guru membagikan LKS materi persegi untuk didiskusikan setiap kelompok.

c. Pengamatan

Pelaksanaan pengamatan proses pembelajaran pada siklus ini, siswa sebagian besar antusias mengikuti pembelajaran, hal ini terlihat dari banyaknya siswa yang menanggapi setiap pertanyaan yang diajukan oleh guru mengenai materi yang diajarkan yaitu materi persegi.

Dalam diskusi kelompok yang terlihat lebih aktif kerja sama dari setiap anggota kelompok dibandingkan dengan siklus I. Dalam kegiatan pertandingan (tournament) siswa kelihatan aktif dan antusias dalam menjawab pertanyaan. Setiap anggota dari masing-masing kelompok sudah memahami betul peraturan dari permainannya, hal ini dibuktikan lancarnya jalannya permainan tersebut.

Pada akhir siklus guru membagikan angket kepada siswa untuk mengungkap motivasi belajar matematika siswa terhadap tindakan yang diberikan.

Hasil evaluasi yang diperoleh oleh siswa setelah pelaksanan model pembelajaran TGT ini menunjukkan hasil rata-rata kelas 69,00.

\section{d. Refleksi}

Dari hasil pengamatan dalam pelaksanaan model pembelajaran TGT, waktu yang tersedia tidak cukup, hanya sampai pada kegiatan permainan, pada kegiatan pemberian penghargaan tidak sempat dilaksanakan, hal ini karena waktu pembelajaran pada bulan Ramadhan dipersingkat, sehingga peneliti dan guru pamong menyepakati untuk terpenuhinya waktu dalam pelaksanaan model pembelajaran TGT pada siklus III, maka pelaksanaannya dirancang dua pertemuan, pertemuan pertama kegiatan menjelaskan materi dan diskusi kelompok, sedangkan pertemuan kedua kegiatan permainan (tournament) dan pemberian penghargaan.

Dari hasil evaluasi yang menunjukkan hasil rata-rata kelas 69,00, ini berarti sudah memenuhi kriteria ketuntasan belajar yang ditetapkan oleh guru mata pelajaran sebesar 63,00 . 


\section{Pembahasan}

Selama kegiatan berlangsung peneliti mendapatkan beberapa kejadian penting yang dianggap dapat mempengaruhi penelitian antara lain:

1. Penerapan pembelajaran kooperatif melalui TGT dapat meningkatkat motivasi belajar siswa.

Berdasarkan hasil dari penyebaran angket dilihat dari tabel 3 dan tabel 4 yaitu tabel motivasi belajar siswa secara umum dihitung jumlah rata-rata setiap aspek yang diukur mengalami kenaikan dari $75 \%$ menjadi $90 \%$ yang terdiri dari kategori motivasi sangat baik, baik dan cukup baik.

2. Permainan dalam TGT ini dapat menimbulkan antusias dan semangat bagi siswa.

Pada saat permainan para pemain pada setiap meja turnamen yang merupakan wakil dari kelompok terlihat bersemangat untuk mampu menjawab pertanyaan yang dibacakan, bahkan sebelum pemain yang gilirannya menjawab, ada penantang yang segera ingin menjawab.

3. Penerapan pembelajaran kooperatif melalui TGT dapat meningkatkat hasil belajar matematika siswa.

Nilai rata-rata siswa setiap siklus mengalami kenaikan. Pada siklus I dengan materi persegi panjang rata-rata hasil nilai siswa 65,40. Pada siklus II dengan materi persegi rata-rata hasil nilai siswa 69,00. Pada siklus III dengan materi jajargenjang rata-rata hasil nilai siswa 68,00 .

\section{KESIMPULAN}

Beberapa kesimpulan yang dapat ditarik dari hasil penelitian tindakan kelas (PTK) ini adalah sebagai berikut:

1. Motivasi belajar matematika siswa secara umum mengalami kenaikan rata-rata motivasi minimal cukup baik yang awalnya sebesar $75 \%$ siswa menjadi sebesar 90 $\%$ siswa di kelas X. Hal ini menurut analisis peneliti dikarenakan sebagai berikut: (1) Siswa senang dengan variasi model pembelajaran yang menurut mereka baru dan belum pernah mereka dapat sebelumnya (2) Materi pembelajaran yang dibahas relatif dapat dipahami oleh siswa karena di jenjang sekolah sebelumnya pernah diajarkan

2. Hasil tes yang dilaksanakan pada setiap siklus mengalami kenaikan, kecuali pada siklus III. Pada siklus I nilai rata-rata sebesar 65,40, pada siklus II nilai rata-rata sebesar 69,00 dan pada siklus III nilai rata-rata sebesar 68,00. Hal ini menurut pengamatan dan pengalaman peneliti dikarenakan bagi siswa materi pada siklus III mengenai jajargenjang relatif lebih sulit dari materi pada siklus I dan II. 
AKSARA: Jurnal Ilmu Pendidikan Nonformal

P-ISSN 2407-8018 E-ISSN 2721-7310 DOI prefix $\underline{10.37905}$

Volume 07, (03) September 2021

http://ejurnal.pps.ung.ac.id/index.php/Aksara

\section{DAFTAR PUSTAKA}

Haryono, Moh.. (2007). Penggunaan Variasi Metode Belajar untuk Membangkitkan Motivasi Belajar Matematika. Widyatama, Vol. 4.

Purwanto, Ngalim. (1996). Psikologi Pendidikan. Bandung. PT. Remaja Rosdakarya.

Sudijono, A. (2005). Pengantar Statistika Pendidikan. PT Raja Grafindo. Jakarta

Suhadi. (2006). Meningkatkan Minat dan Motivasi Belajar Siswa Kelas II SMPN 4 Danau Panggang melalui Model Pembelajaran Kooperatif Tipe TGT (Teams Games Tournaments). http://Suhadinet.wordpress.com. Diakses pada tanggal 15 Agustus 2008.

Suhadi. (2008). Model Pembelajaran Kooperatif tipe TGT (Teams Games Tournaments). http://Suhadinet.wordpress.com. Diakses pada tanggal 15 Agustus 2008.

Sumanto, Wasty. (1984). Psikologi Pendidikan (Landasan Kerja Pemimpin Pendidikan. Yogya. Yayasan Paramita.

Sutikno, Sobry. (2007). Menggagas Pembelajaran Efektif dan Bermakna. Bandung. NTP Press.

Trianto, Drs. (2007). Model-model Pembelajaran Inovatif Berorientasi Konstruktivistik. Surabaya. Prestasi Pustaka. 
AKSARA: Jurnal Ilmu Pendidikan Nonformal

P-ISSN 2407-8018 E-ISSN 2721-7310 DOI prefix $\underline{10.37905}$

Volume 07, (03) September 2021

http://ejurnal.pps.ung.ac.id/index.php/Aksara

1178 AKSARA: Jurnal Ilmu Pendidikan Nonformal 